\title{
ANALISIS PEMBERDAYAAN SOSIAL EKONOMI DI MASJID AT-TAQWA ${ }^{\prime \prime}$
}

\author{
Setianto \\ Mahasiswa Program Studi S1Ekonomi Islam -Fakultas Ekonomi dan Bisnis, UniversitasAirlangga \\ Email: Huzztian@yahoo.com \\ Tika Widiastuti \\ Departemen Ekonomi Syariah - Fakultas Ekonomi dan Bisnis - Universitas Airlangga \\ Email: Widasus@yahoo.com
}

\begin{abstract}
:
This research aims to find out the role of At-Taqwa mosque in Simorejo Surabaya towards the community. It uses qualitative approach with descriptive case study methodology. The researcher used purposive technique for data collection to determine the informant. Based on the technique, the researcher obtained seven informants which were the head of takmir, and six mosque jamaah from At-Taqwa Simorejo Surabaya. The data collection was done by doing observation, documentation, and in-depth interview. The analysis of the data was done by using interactive model which were data reduction, data display and drawing the conclusion.

The result is At-Taqwa Simorejo mosque has a big role in social empowerment because the community is involved in productive process which is based on equality and security, sustainability and cooperation which can run simultaneously so that prosperity can be achieved.
\end{abstract}

Keywords: mosque, empowerment, social and economics.

\section{PENDAHULUAN}

\section{Latar Belakang}

Indonesia merupakan negara dengan jumlah muslim terbesar di dunia. Tidak mengherankan jika tempat beribadah umat muslim banyak bertebaran di seantero negeri ini, baik yang berukuran besar atau pun kecil. Tempat beribadah dalam konteks tulisan ini ialah masjid. Masjid merupakan pranata keagamaan yang tidak terpisahkan dari kehidupan spiritual, sosial dan kultur umat islam. Secara umum masjid selain sebagai tempat ibadah juga memiliki banyak fungsi diantaranya ialah bidang sosial, pendidikan dan pemersatu umat.

Surabaya selain kota terbesar kedua di Indonesia juga merupakan kota dengan hampir $81 \%$ penduduknya beragama Islam (Kemenag, 2010). Dengan jumlah mayoritas muslim, tidak mengherankan masjid begitu mudah ditemui di Surabaya. Menurut data kementrian agama (kemenag) jumlah masjid di Surabaya berjumlah 1.052 dan terus tumbuh hingga 17\% hingga 2010 (Kemenag, 2010).

Tabel 1.

Jumlah Masjid di Kota Surabaya tahun 2006-2010

\begin{tabular}{|l|l|l|l|l|l|}
\hline & 2006 & 2007 & 2008 & 2009 & 2010 \\
\hline Masjid & 963 & 1.033 & 1.068 & 1.093 & 1.138 \\
\hline
\end{tabular}

Sumber: Kantor Departemen Agama (Kemenag) kota Surabaya

Secara teori-konseptual, masjid merupakan pusat kebudayaan Islam, dari tempat inilah syiar keislaman yang

\footnotetext{
1) jurnal ini merupakan bagian dari skripsi yang ditulis oleh Setianto, NIM: 040811619 yang diuji pada tanggal 18 Mei 2015
} 
meliputi aspek duniawi dan ukhrawi, material-spiritual dimulai. Masjid menempati posisi yang istimewa dalam doktrin dan kultur Islam. Hal ini dikarenakan masjid menjadi pilar spiritual yang menyangga kehidupan duniawi umat. Masjid juga memiliki peranan strategis untuk kemajuan peradaban umat Islam. Sejarah mencatat peranan multifungsi masjid tersebut (Gazalba, 1975:55).

Masjid dalam Al-Quran disebut sebanyak 28 kali (Shihab, 2000:9). Semua kata masjid tersebut berintikan ketundukan insan pada Khalik-Nya. Ayatayat Al-Quran yang berisikan kata masjid tersebut secara garis besar menerangkan dua hal. Pertama, tentang fungsi teologis masjid, yaitu tempat untuk melakukan aktivitas yang mengandung ketaatan, kepatuhan dan ketundukan kepada Allah SWT. Kedua, fungsi peribadatan masjid yang menyatakan bahwa masjid ialah tempat untuk membangun nilai taqwa (Roqib, 2005:73).

Realitas yang terjadi saat ini ialah bahwa semangat membangun masjid tidak diikuti oleh kemauan untuk memakmurkan masjid. Semangat memakmurkan masjid hanya terkesan pada bentuk bangunan dan kemegahan tidak dalam bentuk menghidupkan kegiatan masjid baik yang berhubungan dengan kegiatan peribadahan dan non peribadahan (Al-Farq, 2010: 71). Al-Quran menerangkan tentang memakmurkan masjid pada surat At-Taubah ayat 18:

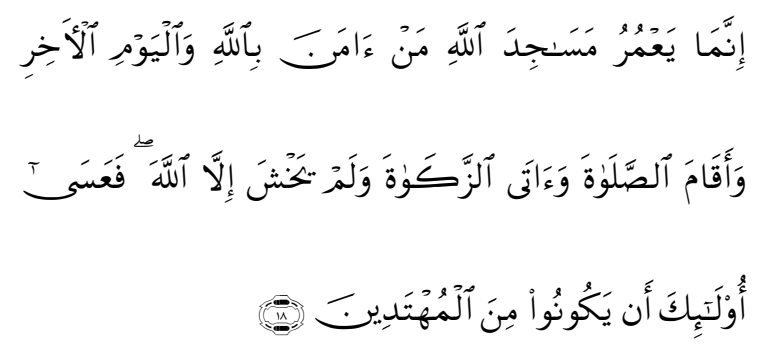

innamā ya'muru masājida 'I-Lāhi man'āmana bi'l-Lāhi wālyawmi'l-akhiri wa'aqāma şalawātạ wa'atā-zzakawāta walam yakhsya illā'l-Lāha fa'asā ulā'ika 'an yakūnū mina'l-muhtadína

Artinya: "Hanya yang memakmurkan masjid-masjid Allah ialah orang-orang yang beriman kepada Allah dan hari Kemudian, serta tetap mendirikan shalat, menunaikan zakat dan tidak takut (kepada siapapun) selain kepada Allah, Maka merekalah orangorang yang diharapkan termasuk golongan orang-orang yang mendapat petunjuk" (QS At-Taubah:81)

Ayat tersebut menerangkan kriteria memakmurkan masjid. Kriteria tersebut meliputi unsur beriman kepada Allah dan hari kiamat, mendirikan shalat, menunaikan zakat dan tidak takut kepada selain Allah. Ayat tersebut tidak hanya ditujukan kepada takmir masjid, melainkan kepada semua jamaan masjid dan umat Islam. Takmir masjid ialah sekelompok orang dari jamaah masjid yang mengemban amanah dan 
tanggung jawab terdepan dalam memakmurkan masjid (Al-Faruq, 2010:71).

Masjid yang secara umum dikenal sebagai pusat peribadatan memiliki potensi pemberdayaan yang potensial. Tidak hanya pemberdayaan spiritual yang selama ini dikenal, tetapi juga pemberdayaan materi berupa sosialekonomi bagi umat pada khususnya dan masyarakat pada umumnya. Sejarah mencatat bagaimana masjid pada masa nabi menjadi sentra kegiatan sosial, ekonomi, budaya dan politk.

Masih dapat ditemui masjid yang berdiri besar dan megah ditengah pemukiman yang miskin. Islam sebagai agama yang menekankan kesetiakawanan sosial menolak hal ini. Masjid yang megah haruslah membawa pengaruh yang positif bagi sosial ekonomi masyarakat sekitarnya tidak hanya sebagai bentuk monumen mati. Peran masjid haruslah meniru teladan Nabi Muhammad dalam memakmurkan Masjid Nabawi.

\section{Tujuan Penelitian}

Tujuan dari penelitian ini ialah, untuk mengetahui peran masjid dalam memberdayakan sosial ekonomi masyarakat. Dalam penelitian ini dikhususkan pada masyarakat di sekitar masjid At-Taqwa Simorejo Surabaya.

\section{LANDASAN TEORI DAN}

PENGEMBANGAN HIPOTESIS

\section{Sejarah Masjid}

Pendirian masjid sangatlah penting dalam masyarakat muslim pada periode awal perkembangan Islam. Hal ini terlihat dimanapun umat Islam menguasai sebuah kota maka masjid akan didirikan kota tersebut. lambat laun seiring makin banyaknya pemeluk Islam maka masjid menjadi hidup dan menjadi pusat cosmopolitan serta menjadi pusat aktivitas masyarakat (Al-Makassary, 2010:43).

Sejak awal perkembangan Islam, mulai dari masa periode klasik hingga modern saat ini, masjid tidak dapat dipisahkan dari umat Islam. Hal ini bermula ketika Nabi Muhammad hijrah ke Yastrib (Madinah). Sesampainya di Madinah pada tahun 622 M, Nabi bersama dengan sahabat Muhajirin dan Anshar membangun masjid pertama. Masjid ini bernama masjid Quba' dan Nabawi. Masjid ini berfungsi sebagai (Kementrian Agama, 2011:4):

1. Tempat pelaksanaan ibadah Mahdlah.

2. Pusat pemerintahan dan layanan publik.

3. Pusat pertemuan dan informasi.

4. Tempat berlatih bela diri dan perang.

5. Balai pengobatan.

6. Tempat mempelajari ilmu.

7. Tempat untuk mengadili perkara.

8. Tempat tawanan perang.

9. Tempat pagelaran seni dan budaya.

10. Serambi masjid untuk ruang menginap tamu.

11. Pusat kegiatan perekonomian. 
Umat Islam sesudah masa Nabi Muhammad, sejak masa Khulafa alrasyidin, masa Bani Umayah, Masa Bani Abbas, Daulah Fatimiyah dan hingga kini masih menjadikan optimaliasi peran masjid pada zama Nabi sebagai tauladan (Al-Makassary, 2010: 43).

Perkembangan masjid di Indonesia dimulai pada zaman walisongo. Keberadaan masjid di Indonesia memiliki peran yang signifikan dan strategis. Berikut merupakan peran masjid tersebut (AIMakassary, 2010:43):

1. Sebagai pusat penyebaran dakwah dan pendidikan Islam.

2. Pusat pemersatu umat dan bangsa.

3. Tempat penyelesaian perdata dan pidana zaman kerajaan Islam.

4. Pusat sosialiasi dan institusional hukum Islam sehingga menjadi hukum yang hidup.

5. Pusat informasi sejarah pertumbuhan dan perkembangan kebudayaan dan peradaban Islam.

6. Pusat pemberdayaan masyarakat dalam bidang ekonomi, sosial dan politik.

7. Salah tujuan wisata budaya dan religius.

\section{Fungsi Dan Tujuan Didirikan Masjid}

Fungsi utama masjid ialah sebagai tempat umat muslim untuk bersujud kepada Allah SWT, sedangkan bangunan masjid yang didirikan umat muslim bertujuan untuk melaksanakan shalat berjamaah dan berbagai keperlvaan lainya terkait dengan kemaslahatan umat serta mempunyai tujuan untuk meningkatkan solidaritas dan silahturahmi antar umat muslim.

Fungsi dasar masjid menurut Shihab (1996:26) dapat dilihat dalam AlQuran yang menyebutkan fungsi masjid antara lain di dalam Surat an-Nuur ayat 36 dan 37:

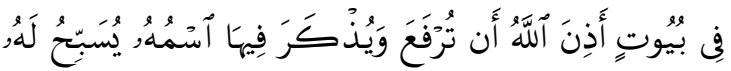

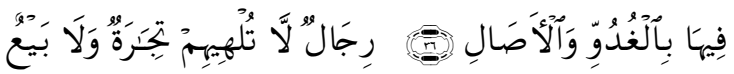

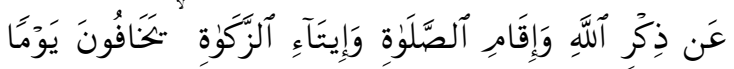

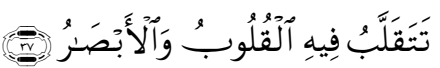

fỉbuyūtin ażina'l-Lāhu 'anturfa'a wayużkara fịhāsmuhu yusabbihu lahu fihā bi'l-ghuduwwi wa'l aşāli, rijālun lā tulhîhim tijāratun walābay'un 'an żikri'l-Lāhi wa'iqāmişşalāti wa'îytā-izzakawāti yakhāfūna yawman tataqallabu fihi'lqulūbu wāl-abşāru

Artinya: "Di dalam masjid-masjid sebagai tempat yang diperintahkan Allah untuk memuliakan dan menyebut namaNya dengan bertasbih, pada waktu pagi dan waktu petang, laki-laki yang tidak dilalaikan oleh perniagaan dan tidak (pula) oleh jual beli dari mengingati Allah, dan (dari) mendirikan sembahyang, dan (dari) membayarkan zakat, mereka takut kepada suatu hari yang (di hari itu) hati 
dan penglihatan menjadi goncang." (QS. An-Nuur: 36-37).

Fungsi dasar masjid adalah sebagai tempat kembalinya manusia untuk beribadah dan bersujud kepada Allah dalam setiap menyelesaikan aktivitas dari kegiatan bekerja, yang dibangun agar umat mengingat, mensyukuri dengan mengeluarkan zakat dan menyembah-Nya dengan baik. Allah juga memerintahkan dengan mengikatkan diri dengan-Nya dan menyucikan dari najis, permainan yang melalaikan dan ucapan serta perbuatan yang tidak pantas (Shihab, 1996:27).

Pada zaman Rasulullah, masjid tidak hanya digunakan sebagai tempat untuk beribadah, tetapi juga menjaid tempat kegiatan umat muslim. Diantaranya kegiatan dibidang pemerintahan yang mencakup ideologi, politik, ekonomi, sosial, peradilan dan kemiliteran. Selain itu masjid juga sebagai pusat pengembangan kebudayaan dan pendidikan Islam.

Masjid memiliki banyak fungsi, baik dalam peribadatan maupun dalam kaitannya meningkatkan harkat umat Islam. Menurut Drs. Moh. Ayub mengemukakan paling sedikit terdapat sembilan fungsi yang dapat diperankan oleh masjid (Rukmana, 2009:39). Diantaranya ialah:

a. Masjid Merupakan tempat kaum muslimin beribadah dan mendekatkan diri kepada Allah SWT. b. Masjid merupakan tempat kaum muslimin beriktikaf, membersihkan diri, penggemblengan batin/keagamaan sehingga selalu terpelihara keseimbangan jiwa dan raga serta keutuhan kepribadian.

c. Masjid adalah tempat bermusyawarah kaum muslimin guna memecahkan persoalanpersoalan yang timbul dalam masyarakat.

d. Masjid adalah tempat kaum muslimin berkonsultasi, mengajukan kesulitan-kesulitan, meminta bantuan dan pertolongan.

e. Masjid adalah tempat membina keutuhan ikatan jamaah dan kegotongroyongan didalam mewujudkan kesejahteraan bersama.

f. Masjid dengan majelis taklimnya merupakan wahana untuk meningkatkan kecerdasan dan ilmu pengetahuan.

g. Masjid adalah tempat pembinaan dan pengembangan kader-kader pimpinan umat.

h. Masjid tempat menghimpun dana, menyimpan dan membagikannya.Masjid tempat melaksanakan pengaturan dan supervise sosial.

\section{Pemberdayaan Sosial Ekonomi} Konsep pemberdayaan masyarakat menjadi primadona di era 
demokrasi saat ini. Hal ini dikarena konsep pemberdayaan menempatkan masyarakat tidak sebagai pihak yang serba kekurangan (kekurangan di bidang politik, sosial dan ekonomi) dan objek pasif penerima bantuan belaka, melainkan sebagai pihak yang memiliki beragam kemampuan yang dapat dimobilisasi untuk memperbaiki hidupnya (Baryadi dkk, 1998:51).

\section{Definisi Pemberdayaan Masyarakat}

"Pemberdayaan menurut bahasa berasal dari kata daya yang berarti tenaga atau kekuatan. Pemberdayaan adalah upaya membangun sumber daya dengan mendorong, memotivasi dan meningkatkan kesadaran akan potensi yang dimiliki serta berupaya untuk mengembangkannya" (Mubyarto, 2000: 263).

Istilah pemberdayaan adalah terjemahan dari istilah asing yaitu empowerment. Secara leksikal pemberdayaan berarti penguatan. Sedangkan secara teknis pemberdayaan dapat disamakan atau setidaknya diserupakan dengan istilah pengembangan. Lebih jauh kedua istilah ini dalam batas tertentu dapat dipertukarkan. Dalam pengertian lain, pemberdayaan atau pengembangan adalah upaya untuk memperluas horizon pilihan bagi masyarakat (Machendrawati dan safei, 2001: 30).

\section{Mendefinisikan pemberdayaan} sebagai penyediaan sumber daya, kesempatan, pengetahuan, dan keterampilan bagi masyarakat untuk meningkatkan kapasitas mereka sehingga mereka bisa menemukan masa depan yang lebih baik(Jim Ife, 1995:63). Pemberdayaan adalah upaya untuk membangun daya yang dimiliki dhuafa dengan mendorong, memberikan motivasi dan meningkatkan kesadaran tentang potensi yang dimiliki mereka serta berupaya untuk mengembangkannya (Sumohadiningrat, 1997: 165), dengan kata lain memberdayakan adalah memampukan memandirikan masyarakat.

Dari pengertian di atas masyarakat diberdayakan untuk melihat dan memilih hal yang bermanfaat bagi dirinya. Dengan memakai logika ini, dapat dikatakan bahwa masyarakat yang berdaya adalah yang dapat memilih dan mempunyai kesempatan untuk mengadakan pilihan-pilihan. Lebih Ianjut proses pengembangan dan pemberdayaan pada akhirnya akan menyediakan sebuah ruang kepada masyarakat untuk mengadakan pilihanpilihan. Karena masyarakat yang berkualitas ialah masyarakat yang dapat memilih dan mengajukan pilihan-pilihan.

\section{Definisi Sosial Ekonomi}

Sosial ekonomi merupakan dua hal yang memiliki keterkaitan erat, akan tetapi kedua topik ini sangat jarang dibahas secara bersamaan. Sosial diambil dari kata "socius" yang artinya kawan (teman). Kawan dalam konteks ini bukan terbatas sebagai teman sepermainan, 
teman kerja dan sebagainya. Teman dalam konteks ini ialah mereka yang ada disekitar kita, yakni yang tinggal dalam lingkungan tertentu dan mempunyai sifat yang saling mempengaruhi. Dalam Kamus Besar Bahasa Indonesia (KBBI, 1996:958) kata sosial berarti segala sesuatu yang berkenaan dengan masyarakat. Jika dilihat dari konsep sosiologi, manusia sering disebut sebagai makhluk sosial yang artinya manusia tidak tahan hidup wajar tanpa adanya bantuan orang lain disekitarnya. Sehingga kata sosial sering diartikan sebagai hal-hal yang berkenaan dengan masyarakat.

Sementara istilah ekonomi diambil dari kata Yunani yaitu "oikos" yang berarti kelvarga atau rumah tangga dan "nomos" yaitu peraturan, aturan, hukum. Kamus Besar Bahas Indonesia mendefinisikan ekonomi sebagai ilmu mengenai asas-asas produksi, distribusi dan pemakaian barang-barang serta kekayaan (seperti keuangan, perindustrian dan perdagangan) (KBBI, 1996:251).

$$
\text { Menilik pada beberapa }
$$

pengertian di atas, maka dapat disimpulkan bahwa sosial ekonomi adalah segala sesuatu yang berkaitan dengan pemenuhan kebutuhan masyarakat, antara lain sandang, pangan, perumahan, perndidikan, kesehatan dan lain-lain. Pemenuhan kebutuhan tersebut berkaitan dengan penghasilan. Hal ini sesuai dengan penelitian yang akan dilakukan.

\section{METODE PENELITIAN}

Penelitian tentang peran masjid dalam pemberdayaan sosial ekonomi masyarakat ini dapat dikategorikan sebagai penelitian lapangan (field research) yang menggunakan jenis penelitian kualitatif. Jenis penelitian ini dianggap lebih tepat mempertimbangkan fokus penelitian terkait dengan topik yang dibahas. Fokus ini tentu memerlukan pengamatan yang mendalam guna mendapat setting yang alami atas persoalan yang sedang diteliti.

Metode penelitian kualitatif didefinisikan sebagai metode penelitian yang digunakan untuk meneliti objek dalam kondisi alamiah dimana peneliti sebagai instrumen kunci (Sugiyono 2010:305). Menurut definisi tersebut penting kiranya menjaga objek tetap alamiah. Penelitian kualitatif sebagai prosedur penelitian diproyeksikan dapat menghasilkan data deskriptif atas fenomena yang diamati (Robert Bogdan dan Steve J. Taylor, 1975:42). Oleh karena itu penelitian berkepentingan untuk mengupayakan jawaban-jawaban yang telah ditentukan dalam rumusan masalah - Penelitian ini juga berkepentingan mengetahui peranan Masjid At-Taqwa Simorejo dalam pemberdayaan masyarakat sekitarnya.

Dalam proses wawancara peneliti mengunakan guideline yang telah disiapkan sebelumnya, meski begitu proses wawancara bersifat fleksibel (Semi 
terstruktur). Wawancara ini dilakukan terus-menerus secara berkala hingga data dianggap jenuh.

Dalam proses penggalian data, penelitian ini menggunkan tiga tahap. Tiga tahap ini bersifat siklus, artinya tahaptahap tersebut senantiasa diulangi sementara suatu tahap ditangani. Ketiga tahap tersebut diantaranya ialah: eksloparasi menyeluruh, eksplorasi terfokus dan konfirmasi. Pada tahap eksplorasi menyeluruh, peneliti melakukan pengamatan pada tataran umum begitu juga saat wawancara pertanyaan hanya berkutat pada hal yang bersifat umum terkait makna keberkahan. Tahap eksplorasi terfokus, pengalian data dilakukan secara rinci dan mendalam berkaitan dengan pembiayaan dan makna keberkahan. Tahap konfirmasi dilakukan peneliti untuk menguji kredibilitas data. dalam tahap konfirmasi ini peneliti melakukan dua hal:

1. Member Check, yaitu mengkonfirmasi temuan penelitian kepada subyek penelitian dengan meminta tanggapan (Moleong, 2000:181).

2. Triangulasi sumber data, yaitu pemeriksaan keabsahan data yang memanfaatkan sesuatu yang lain di luar data itu untuk keperluan pengecekan atau sebagai pembanding data itu (Moleong, 2000:178).

3. Triangulasi dapat dilakukan dengan menggunakan teknik yang berbeda (Nasution, 2003:115) yaitu wawancara, observasi, dan dokumen. Triangulasi sumber selain digunakan untuk memperkaya data triangulasi juga dapat berguna untuk menyelidiki validitas tafsiran peneliti terhadap data karena triangulasi bersifat reflektif (Sugiyono, 2013:327).

Triangulasi dengan sumber artinya membandingkan dan mengecek balik derajat kepercayaan suatu informan yang diperoleh melalui waktu dan alat yang berbeda dalam penelitian kualitatif (Patton, 1987:331). Adapun untuk mencapai kepercayaan tersebut maka ditempuh dengan langkah berikut (Moleong, 2004:304) :

a. Membandingkan data hasil pengamatan dengan data hasil wawancara.

b. Membandingkan apa yang dikatakan orang di depan umum dengan apa yang dikatakan secara pribadi.

c. Membandingkan keadaan dan perspektif seseorang dengan berbagai pendapat dan pandangan masyarakat dari berbagai kelas.

d. Membandingkan apa yang dikatakan orang-orang tentang situasi penelitian dengan apa yang dikatakannya sepanjang waktu. 
e. Membandingkan hasil wawancara dengan isu suatu dokumen yang berkaitan.

Penggumpulan data sekunder dilakukan dengan melakukan studi literatur. Studi literatur ini digunakan sebagai pijakan penelitian terkait pemberdayaan sosial ekonomi.

Konsep dasar analisis data adalah mengkoordinasikan dan mengurutkan data dalam pola, kategori dan satua uraian dasar sehingga ditemukan tema dan dapat dirumuskan hipotesis kerja atas pembacaan terhadap data (Moleong, 2002:103). Guna memenuhi konsep dasar analisis tersebut digunakan metode menurut Mathew B. Miles dan A. Michael Huberman (1992), yang menawarkan metode analisis interaktif, yakni melakukan analisa data secara simultan dan terus menerus sejak pengumpulan data dilakukan hingga selesainya pengumpulan data dalam waktu tertentu melalui proses: [1] Reduksi data (data reduction]; [2] penyajian data (data display), dan; [3] penarikan kesimpulan (conclution: drawing/verifying) (Miles dan Huberman, 1992: 20).

Dalam proses reduksi data (data reduction), peneliti akan merangkum dan memilih hal-hal pokok dari data yang sementara diperoleh kemudian dicari tema atau kategorisasi. Dalam proses ini, akan didapatkan gambaran yang lebih jelas untuk menentukan langkah pengumpulan data selanjutnya bahkan sampai menentukan cara mengumpulkannya.

Proses selanjutnya berupa penyajian data (data display) yakni data penelitian yang sudah direduksi, dilakukan proses penarasian data dalam bentuk teks. Pada tahap display data penelitia akan melakukan analisa data dengan menggunakan teknik triangulasi. Peneliti melakukan triangulasi dengan membandingkan tiga Sumber yaitu [1] Wawancara [2] Dokumen dan [3] observasi.

Langkah berikutnya berupa penarikan kesimpulan (conclution: drawing/verifying) yang bersifat sementara. Sebab dari kesimpulan sementara ini akan ditindak lanjuti dengan proses verifikasi menggunakan metode triangulasi. Jika dirasa kurang akurat peneliti mengulang proses mengumpulkan data yang kurang, reduksi, display dan penarikan kesimpulan lagi. Proses ini akan berlangsung secara berurutan, berulangulang, terus menerus sampai penelitian ini sampai pada tingkat jenuh dan akurat. Setelah dirasa penelitian telah akurat, barulah disusun sebuah teks naratif dari keseluruhan hasil penelitian.

\section{HASIL PENELITIAN DAN PEMBAHASAN}

Pemberdayaan sebagaimana dipaparkan pada bab sebelumnya merupakan suatu usaha untuk menyediakan sumberdaya, kesempatan, pengetahuan dan keterampilan bagi masyarakat untuk meningkatkan kapasitas mereka sehingga dapat menemukan 
masa depan yang lebih baik. Dimana pemberdayaan setidaknya mencakup pemberdayaan atas aset manusi (human asset), Pemberdayaan Aset modal keuangan (financial asset), dan pemberdayaan aset sosial (Sosial asset).

Pemberdayaan yang akan
dianalisa pada sub ini ialah pemberdayaan terkait dengan sosial ekonomi masyarakat. Dimana pada bab sebelumnya didefinisikan sebagai segala sesuatu yang terkait dengan pemenuhan kebutuhan masyarakat, diantaranya sandang, pangan, papan, pendidikan dan kesehatan. Menurut Ayub (1996:9) masjid dapat menjadi pusat pemberdayaan sosial ekonomi masyarakat.

Pemberdayaan sosial ekonomi masyarakat dapat dilaksanakan oleh masjid jika memenuhi beberapa hal berikut:

1. Masjid adalah tempat menghimpun dana umat, menyimpan dan membagikannya.

2. Masjid menjadi tempat menumbuh kembangkan semangat gotong royong, kebersamaan dan kesetiakawanan sosial.

3. Meningkatkan taraf hidup umat, terutama kaum dhuafa dan miskin,

4. Meningkatkan kecerdasan dan kehidupan sosial ekonomi umat melalui pendidikan dan usaha ekonomi.

5. Memberikan pertolongn dan pelayanan kepada masyarakat

$$
\begin{aligned}
& \text { yang memerlukan melalui } \\
& \text { berbagai kegiatan sosial. }
\end{aligned}
$$

\section{Masjid adalah Tempat Menghimpun Dana} Umat, Menyimpan dan Membagikannya.

Masjid sejak zaman Rasullulah salah satu nya berfungsi sebagai pusat kegiatan perekonomian. Dimana masjid juga menjadi pusat baitul maal atau dapat diartikan sebagai pusat perbendaharaan umat. Melalui baitul maal harta disimpan dan didistribusikan sesuai denga tuntunan syariah. Menilik hal tersebut tentunya tidaklah aneh jika saat ini masjid dapat dijadikan sentral untuk menghimpun, menyimpan dan membagikan dana umat sebagaiman teladan Nabi.

$$
\text { Masjid At-Taqwa Simorejo }
$$

berdasarkan data penelitian menghimpun dana dari umat, mekanismenya melalui kaleng sedekah, donatur dan dompet amaliyah. Hal ini dibenarkan hampir oleh seluruh informan. Kaleng sedekah dibuka dengan setiap hari juma'at dan disaksikan oleh jama'ah. Hal ini dilakukan untuk menghindari fitnah. Mekanisme ini dibenarkan oleh informan pertama, kedua dan keempat. Untuk donatur rutin setidaknya terdapat 150 donatur tetap. Dana yang dihimpun semua berasal dari swadaya masyarakat tanpa bantuan dari pemerintah.

Dana yang disimpan di Bank Rakyat Indonesia (BRI) dalam jangka waktu yang cukup pendek karena biaya operasional masjid yang cukup besar. Informan membenarkan hal ini dan 
didukung oleh informan keempat. Dana yang dihimpun dari umat digunakan untuk mensejahterakan masjid dan pelayanan kepada masyarakat. Menurut informan pertama semua kegiatan yang dilaksanakan tentunya memerlukan biaya.

\section{Masjid Menjadi Tempat Menumbuh} Kembangkan Semangat Gotong Royong, Kebersamaan dan Kesetiakawanan Sosial. Salah satu fungsi masjid selain sebagai tempat untuk beribadah ialah sebagai sarana untuk memperkuat ukhuwah islamiyah. Semangat persaudaraan ini dikembangkan sejah zaman Rasullulah dan terbukti berhasil menyatukan umat Islam pada masa itu. Islam mengajarkan bahwa sesama pemeluk Islam ialah bersaudara. Tidak hanya itu Islam ialah Rahmatan lil allamin yang berarti maha pengasih bagi semua mahkluk di bumi. Masjid yang merupakah rumah Allah haruslah mengadaptasi ajaran tersebut, untuk selalu menumbuhkan kesetiakawanan sosial dan gotong royong.

Data penelitian memperlihatkan bahwa Masjid At-Taqwa melakukan pengumpulan dana untuk memberi bantuan untuk bencana alam, selain itu pendirian panti asuhan merupakan salah satu bentuk usaha untuk menumbuhkan semangat kesetiakawanan sosial. Tidak hanya sebatas itu Masjid At-Taqwa juag memberi bantuan dana kesehatan meski tidak besar. dana bantuan tersebut diambil dari dana yang dihimpun dari jamaah.
Meningkatkan Taraf Hidup Umat, Terutama

\section{Kaum Dhuafa dan Miskin}

Indikator ini sesuai dengan definisi pemberdayaan untuk meningkatkan kapasitas masyarakat dapat menentukan masa depan yang lebih baik. Masjid dapat memerankan peran ini dalam hal pemberdayaan vamt. Indikator ini juga merupakan cakupan dari pemberdayaan Aset modal keuangan (Financial Asset).

Madjid At-Taqwa Simorejo jika dilihat dari data penelitian memperlihatkan usaha untuk itu. Informan ke lima dan ke enam menyatakan pernah ada pelatihan menjahit akan tetapi tidak berjalan lama. Masjid At-Taqwa banyak memberi bantuan berupa penyaluran sedekah kepada kaum dhuafa dan pendirian panti asuhan merupakan salah satu usaha penyaluarn dana sedekah. Akan tetapi ini tidak sesuai dengan arti pemberdayaan yang berarti menguatkan kemampuan umat lebih-lebih meningkatkan taraf hidup.

Meningkatkan Kecerdasan dan Kehidupan Sosial Ekonomi Umat Melalui Pendidikan dan Usaha Ekonomi.

Pemberdayaan yang bertujuan untuk menguatkan (Empowering) masyarakat tentunya dimulai dengan meningkatkan kecerdasan dan skill dari masyarakat sendiri. Hal ini dilakukan dengan harapan masyarakat tersenbut pada akhirnya dapat berdiri sendiri tanpa perlu terus menggantungkan hidupnya kepada orang lain baik secara sosial maupun ekonomi. Selain itu dari segi 
cakupan pemberdayaan, indikator ini merupakan suatu bentuk pemberdayaan Aset manusia (Human asset) dan Aset sosial (Social Asset).

Data penelitian menunjukan bahwa pendirian TK dan Paud oleh Masjid At-Taqwa merupakan suatu bentuk usaha untuk mencerdaskan umat, pengajian yang diadakan rutin juga merupakan bentuk usaha untuk mencerdaskan kehidupan sosial disamping merupakan kegiatan peribadatan. Dengan pengajian rutin masyarakat dapat berinteraksi sehingga memperkuat persaudaraan antar umat.

Segi ekonomi dan usaha ekonomi pernah dilakukan oleh masjid At-Taqwa berupa pelatihan menjahit untuk ibu-ibu. Akan tetapi usaha ini tidak berjalan lancar dan berhenti. Selain itu hampir semua informan tidak pernah mengetahui masjid AtTaqwa mendirikan usaha berupa UMKM. Hanya informan pertama yang bercitacita ingin membuatnya. Akan tetapi tidak dalam waktu dekat. Karena informan pertama lebih memperioritaskan pendirian lembaga pendidikan berupa sekolah dasar hingga sekolah menengah atas.

Memberikan Pertolongan dan Pelayanan Kepada Masyarakat yang Memerlukan Melalui Berbagai Kegiatan Sosial

Memberi pelayanan kepada umat merupaskan salah satu tujuan dari pendirian masjid. Pada masa Rasullulah banyak pelayanan yang diberikan menggunakan wahana masjid. Seperti pelayanan konsultasi dan kesehatan.
Indikator dapat menunjukan seberapa besar peran masjid menjadi sandaran umat untuk mendapatkan pertolongan.

Masjid At-Taqwa sangat bagus pada indikator ini. Dimana masjid AtTaqwa memberikan pelayanan khitanan massal, bantuan pengobatan gratis, pendirian klinik gratis dan pendirian panti asuhan. Semua pelayanan tersebut diberikan secara gratis. Meski begitu beberapa pengguna layanan ini tetap memberikan imbalan sebatas hanya sebagai ucapan terima kasih dan tidak memberatkan.

\section{SIMPULAN DAN SARAN}

Masjid seharusnya memiliki fungsi dan peran tidak hanya sebatas sebagai tempat peribadatan tetapi juga sebagai pusat pemberdayaan umat. Pemberdayaan ini dilakukan agar umat dapat meningkatkan kapasitasnya baik secara sosial maupun ekonomi sehingga mampu menemukan masa depan yang lebih baik.

Peran masjid pada pemberdayaan sosial ekonomi dapat diukur dari indikator sebagai berikut:

1. Masjid adalah tempat menghimpun dana umat, menyimpan dan membagikannya.

2. Masjid menjadi tempat menumbuh kembangkan semangat gotong royong, kebersamaan dan kesetiakawanan sosial.

3. Meningkatkan taraf hidup umat, terutama kaum dhuafa dan miskin, 
4. Meningkatkan kecerdasan dan kehidupan sosial ekonomi umat melalui pendidikan dan usaha ekonomi.

5. Memberikan pertolongan dan pelayanan kepada masyarakat yang memerlukan melalui berbagai kegiatan sosial.

Pada studi ini didapatkan bahwa masjid At-Taqwa Simorejo Surabaya telah berperan dalam melakukan pemberdayaan sosial. Hal ini dibuktikan dari terpenuhinya indikator pertama, kedua dan kelima. Sedangkan dalam pemberdayaan ekonomi, masiid AtTaqwa belum memiliki peran oleh karena tidak memenuhi indikator ketiga dan keempat hal ini disebabkan kurangnya sumberdaya baik manusia maupun dana.

\section{Saran}

Saran yang dapat disampaikan

penulis melalui penelitian ini adalah:

1. Perlunya peningkatan usaha pemberdayaan dibidang ekonomi. Hal ini dapat dimulai dengan pelatihan-pelatihan kewirausahaan yang dapat menggandeng pemerintah kota.

2. Forum-forum pengajian dapat digunakan sebagai sarana pemberdayaan sosial ekonomi disela-sela pelajaran agama.

3. Peneliti selanjutnya diharapkan mampu meneliti lebih dalam terkait pemberdayaan sosial ekonomi oleh masjid.

\section{DAFTAR PUSTAKA}

Al-Faruq, Asadullah. 2010. Panduan Lengkap Mengelola dan Memakmurkan Masjid. Solo: Pustaka Arafah

Ayub, Mohammad E. 1996. Manajemen Masjid: Petunjuk Praktis Bagi Para Pengurus. Jakarta: Gema Insani

Faridl, Miftah.1996. Imaratul Masjid: Pembinaan Masyarkat Muslim melalui Pemakmuran Masjid. Bandung: Yayasan Silaturahmi

Firdaus, Ismet, dan Zaky, Ahmad. 1997. Upaya Meningkatkan Equity Perempuan Dhuafa Desa Bojong Indah Parung. Jakarta: Dakwah Press,

Gazalba, Sidi. 1975. Masjid Pusat Ibadat Dan Kebudayaan Islam. Jakarta: Pustaka Antara

------. 1989. IImu, Filsafat dan Islam tentang Manusia dan Agama. Jakarta: PT Bulan Bintang

Kemenag Surabaya. 2010. Jumlah Masjid di Kota Surabaya. Surabaya: Pusat Data Kemenag.

Machendrawati, dkk. 2001. Penegmbangan Masyarakat Islam; Dari Ideologi, Strategi Sampai Tradisi. Bandung: Rosida, 2001.

Mubyarto. Membangun Sistem Ekonomi. Jogjakarta: BPFE, 2000

Rukmana, Nana. 2009. Manajemen Masjid: Panduan Praktis Membangun dan Memakmurkan Masjid. Bandung: MQS Publishing 
Shihab, M. Quraisy. 1996. Wawasan AlQuran. Bandung: Mizan

-----. 2009. Tafsir Al-Misbah: Pesan, Kesan dan Keserasian Al-Quran Vol. 13. Jakarta: Lentera Hati 2009. Tafsir Al-Misbah: Pesan, Kesan dan Keserasian Al-Quran Vol. 14. Jakarta: Lentera Hati

Suharto, Edi. Membangun Masyrakat Memberdayakan Rakyat. Bandung: PT Refika Aditama, 1997

Sugiyono. 2012. Metode Penelitian Kombinasi (Mixed Methods). Cetakan kedua. Bandung: AIFABETA

Sumihadiningrat, Gunawan. 1997.

Pembangunan Daerah Dan

Pengembangan Masyarakat. Jakarta:

Bina Rena Pariwara

Sabiq, Saddiq. 1987. Fikih Sunnah 14. Bandung: PT Alma'arif.

Rahardjo, M. Dawam. 1999. Islam dan Transformasi Sosial-Ekonomi. Yogyakarta: LSAF

Roqib, Moh. 2005. Menggugat Fungsi Edukasi Masjid. Yogyakarta : Grafindo Litera Media dan STAIN Purwokero Press Sitepu, Abdi Zulkarnain. 2005. Pemberdayaan Masyarakat Islam Melalui Pemberdayaan Ekonomi Ummat. Jurnal Pengembangan Masyarakat Islam, (Online), (http://www.

komunitas.wikispaces.com, diakses 25 November 2012)

Yani, Ahmad. 2002. Panduan Memakmurkan Masjid. Jakarta: Dea Press
Yin, Robert. 2009. Studi Kasus dan Metode. Jakarta: PT Raja Grafindo Persada. 